\title{
CONCEPT MAPPING BOOK HUBUNGAN SISTEM ORGAN MANUSIA
}

\author{
Rendi Zulni Ekaputri ${ }^{1 *}$, Bhakti Karyadi ${ }^{1}$, Nur Aliyyah Irsal ${ }^{1}$, Fitra Youpika ${ }^{2}$, Nike Anggraini ${ }^{3}$ \\ ${ }^{1}$ Jurusan Pendidikan Matematika dan IPA, Fakultas Keguruan dan Ilmu Pendidikan, Universitas Bengkulu \\ ${ }^{2}$ Jurusan Bahasa dan Sastra, Fakultas Keguruan dan Ilmu Pendidikan, Universitas Bengkulu \\ ${ }^{3}$ Jurusan Pendidikan Biologi, Fakultas Keguruan dan Ilmu Pendidikan, Universitas Bengkulu \\ email: rzeputri@unib.ac.id
}

\begin{abstract}
Abstrak
Penelitian ini bertujuan untuk mengembangkan bahan ajar berupa concept mapping book hubungan sistem organ yang layak digunakan untuk materi sistem organ bagi mahasiswa Biologi dan Kesehatan serta guru SD, SMP dan SMA. Jenis penelitian ini merupakan penelitian research and development (R\&D) yang terdiri dari tahap pendahuluan berupa kajian kepustakaan dan pengumpulan data/informasi, desain produk, validasi desain, dan revisi desain. Penelitian ini diawali dengan pengidentifikasian dan pendeskripsian sistem organ manusia dari hasil identifikasi dan deskripsi tersebut, kemudian dijadikan sebagai materi untuk pengembangan model pemetaan concept mapping book hubungan sistem organ manusia.Teknik pengumpulan data dilakukan dengan teknik deskriptif berupa kajian pustaka (literature). Instrumen yang digunakan adalah lembar validasi. Produk yang telah dikembangkan kemudian dilakukan validasi dengan melibatkan validator ahli bahan ajar, ahli materi, pengguna (dosen dan mahasiswa) menggunakan lembar validasi untuk diketahui skor penilaian kelayakan dari bahan ajar yang dikembangkan. Aspek penilaian concept mapping book meliputi kebahasaan, materi, dan tampilan. Skor hasil validasi dan uji keterbacaan kemudian dihitung dan ditentukan kriteria kelayakannya. Dari hasil penelitian diperoleh 9 (sembilan) pemetaan concept mapping book hubungan sistem organ manusia. Untuk hasil validasi dari ahli bahan ajar adalah 93,4\% (valid), dari ahli materi 98,86\% (valid) dan dari mahasiswa 80,98\% (valid). Bahan ajar berupa concept mapping book hubungan sistem organ dapat dijadikan bahan ajar pelengkap bagi guru dan mahasiswa.
\end{abstract}

Kata kunci: Concept Mapping Book, Bahan Ajar, Sistem Organ Manusia

\begin{abstract}
This research aims to the develop teaching materials in the form of concept mapping of humans' organ sistem which can be utilized for a proper teaching material to primary school, high school teachers, as well as student in the university. This study is a research and developmental research which is preempted by a literature study, data collection, product design, design validation, and design revision. This study is started with an identification and description on the human's organ sistem. The output is further compiled as a teaching material in developing the concept mapping book of human's organ sistem. The data collection technique was conducted through a descriptive study on the major literature studies. The validation sheet is also used as the instrumental tool. The developed product is then validated by involving an expert in the teaching material design, expert in the human's organ sistem, users (lecturers and students). A weighted score is employed to identify the appropriateness of the developed teaching material product. The evaluation on the concept mapping book covers the depth of analysis, material, and display. The final score of validation is further justified and calculated based on its criteria of appropriateness. The obtained result indicates that there are nine eligible concept mapping to be validated. The validation results from the teaching material expert stands for 93.4 (valid), while the results from content material expert and students are 98.86 (valid) and 80.98 (valid) respectively.Keyword: Concept Mapping Book, Teaching Material, Human Organ Sistem
\end{abstract}




\section{PENDAHULUAN}

Pengetahuan yang baik tidak hanya mentrasnformasi ilmu. Pendidikan adalah domain utama mempersiapkan peserta didik untuk membangun mental dan kepribadian (Shawket, 2016). Kompetensi lulusan yang dituntut pada K-13 yaitu sikap, pengetahuan dan keterampilan (Lampiran Peraturan Menteri Pendidikan dan Kebudayaan Republik Indonesia, 2016). Pengintegrasian pendidikan karakter dalam pengembangan pengetahuan dan keterampilan ditekankan juga dalam kurikulum 2013 (Fahmy, dkk, 2015). Pendidikan karakter bertujuan membangun dan membekali peserta didik (Peraturan Presiden Republik Indonesia, 2017). Penguatan karakter dapat melalui materi dan metode pembelajaran (Ekaputri dkk, 2018). Selain, penguatan karakter kemampuan berpikir kritis juga menjadi penting untuk saat ini. Banyak sekolah dan perguruan tinggi tidak mampu meningkatkan kemampuan berpikir kritis siswanya (Harris \& Shen, 2017).

Peningkatan kemampuan berpikir kritis dan penanaman karakter dapat melalui teknik concept mapping. Concept mapping adalah sarana untuk membangun pengetahuan, memahami apa yang dipikirkan siswanya tentang isi materi, dan memberikan relevansi dan hubungan keterkaitan antar pengetahuan (Campbell L O, 2016). Selain itu, concept mapping adalah alat grafis untuk mengorganisir dan menggambarkan pengetahuan (Lunce C, 2011). Concept mapping membuat pembelajaran terlihat sehingga kualitas pembelajaran yang sebenarnya telah terjadi dapat dilihat dan dieksplorasi (Hay D \& lan K, 2008). Concept mapping mengajak siswa untuk mengerti hubungan antara konsep dengan mengkreasikan hubungan tersebut dalam visual (Akcay, 2010).
Hasil studi terhadap mahasiswa berkaitan dengan materi sistem organ, diperoleh data bahwa materi tersebut terlalu kompleks dan belum terdapat bahan ajar yang mampu menjabarkan materi tersebut secara ringkas padat dan jelas. Sehingga mahasiswa mengharapkan bahan ajar yang bersifat praktis dan aplikatif yang mampu membantu mereka memahami konsep yang kompleks.

Berdasarkan permasalahan tersebut, maka peneliti mencoba mencari solusi mengenai permasalah tersebut. Bahan ajar berbasis concept mapping book mampu menjawab dan memecahkan permasalahan yang dihadapi oleh mahasiswa. Hal ini dikarenakan beberapa penelitian tentang pemanfaatan concept mapping. Salah satunya pemanfaatn concept mapping dalam bidang pendidikan medis, concept mapping mampu mengintegrasikan variasi konsep yang mana setiap bagian memiliki ruang kognitif yang kompleks (Joshi \& Sheetal, 2018). Selain itu, concept mapping dalam sains digunakan untuk mengembangkan pengetahuan dan pembelajaran efektif (Akcay, 2010). Sehingga Siswa memberikan respon positif terhadap kolaborasi concept mapping.

Tujuan dari pengembangan concept mapping book ini adalah untuk menghasilkan bahan ajar berupa model pemetaan concept mapping book hubungan sistem organ manusia. Selain itu, untuk mengetahui respon terhadap model pemetaan concept mapping book hubungan sistem organ manusia. Hal tersebut diharapkan dapat menambah pengetahuan siswa maupun masyarakat luas untuk dijadikan sebagai sumber belajar dengan memanfaatkan model pemetaan concept mapping book hubungan sistem organ manusia, sehingga akan mendukung proses belajar dan pencapaian tujuan pembelajaran yang 
dapat membangkitkan karakter dan berpikir kritis siswa serta mahasiwa.

\section{METODE}

Jenis penelitian ini adalah
penelitian dan pengembangan atau
Research and Development (R\&D) Research and Development (R\&D). Penelitian R \& D dalam bidang pendidikan digunakan untuk mengembangkan dan memvalidasi produk- produk pendidikan. Pengembangan bahan ajar dilakukan dengan menggunakan model pengembangan yang terdiri dari 10 tahap yaitu potensi dan masalah, pengumpulan data, desain produk, validasi desain, revisi desain, ujicoba produk, revisi produk, ujicoba pemakaian, revisi produk, dan produksi massal (Sugiyono, 2008). Namun pada penelitian ini hanya dibatasi sampai tahap revisi desain (potensi dan masalah, pengumpulan data, desain produk, validasi desain, revisi desain).

Pada tahap potensi dan masalah dilakukan kegiatan studi pustaka tentang Concept mapping book dimana peneliti mencari litaratur yang berhubungan dengan sistem organ manusia. Setelah itu tahap pengumpulan data yaitu dengan pengembangan Studi pustaka tentang Concept mapping book merupakan proses penyusunan materi pembelajaran yang dikemas secara sistematis sehingga siap digunakan oleh peserta didik. Dalam proses pengembangan Concept mapping book pembelajaran terdapat langkahlangkah sebagai berikut: studi Pendahuluan, pada tahap ini terdiri atas tiga langkah, pertama pengukuran kebutuhan, kedua studi literatur, dan ketiga penyusunan produk awal atau draf model dan Pengembangan Concept mapping book, berdasarkan dari hasil studi literatur dan studi pendahuluan yang dilakukan peneliti maka dapat dilakukan pengembangan draf.
Tahap Penyusunan desain draft
Concept mapping book dapat dilaksanakan dengan mengikuti langkahlangkah sebagai berikut: menganalisis silabus, mengumpulkan referensi sebagai bahan penulisan, mengevaluasi hasil tulisan dengan cara dibaca ulang, memperbaiki Concept mapping book sesuai dengan kekurangan yang ditemukan, menggunakan berbagai sumber belajar yang dapat memperkaya materi Concept mapping book. Tahap Validasi ahli merupakan proses untuk menguji kesesuaian Concept mapping book dengan kompetensi yang menjadi target belajar. Data yang diperoleh dari tahap validasi adalah data kuantitatif yang diperoleh dari skor lembar penilaian yang diisi oleh validator dan data kualitatif yang diperoleh dari saran dan kritik validator. Tahap Revisi Produk atau perbaikan merupakan proses penyempurnaan Concept mapping book setelah memperoleh masukan dari kegiatan validasi. Maka perbaikan Concept mapping book harus mencakup aspekaspek penting dari komponen Concept mapping book.

Instrumen yang digunakan untuk mengumpulkan data kelayakan bahan ajar berupa lembar validasi. Lembar validasi digunakan untuk mengumpulkan informasi kelayakan Concept mapping book dan uji keterbacaan terhadap Concept mapping book. Subjek Penelitian adalah ahli bahan ajar, ahli materi dan pengguna (Mahasiswa).

Penelitian ini menggunakan metode deskriptif kuantitatif. Kuantitatif Data berupa skor validasi bahan ajar dari ahli biologi, ahli bahan ajar,dan pengguna. Data kuantitatif berupa skor validasi akan diterjemahkan ke dalam data kualitatif yang berbasis deskriptif. Kajian dokumen atau studi pustaka pada penelitian ini meliputi analisis buku-buku yang 
berhubungan dengan hubungan sistem organ manusia, Jurnal nasional, artikel maupun hasil penelitian yang relevan tentang pengembangan Concept mapping book. Data mengenai hasil validasi oleh ahli materi, ahli bahan ajar dan guru dianalisis dengan menggunakan rumus dari Arikunto (2012):

$$
P=\frac{\sum x}{\sum x i} x 100 \% \text { (Arikunto, 2012) }
$$

Keterangan $: \mathrm{P}=$ Persentase Kevalidan

$\Sigma x=$ jumlah seluruh skor jawaban responden per item

$\Sigma x i=$ Jumlah seluruh skor ideal per item

Berdasarkan perhitungan

persentase pengambilan keputusan mengenai kevalidan mengacu pada Tabel 1.

Tabel 1 Kriteria Kevalidan Data dan Pengambilan Keputusan Revisi

\begin{tabular}{ccc}
\hline Skala Nilai (\%) & Keterangan & Keputusan Uji \\
\hline $86-100$ & Sangat valid & Sangat layak dan tidak revisi jika mencapai 100\% \\
$71-85$ & Valid & Layak namun tetap dilakukan revisi kecil \\
$56-70$ & Cukup valid & Cukup layak dan perlu revisi besar \\
$41-55$ & Kurang valid & Kurang layak dan perlu revisi besar \\
$25-20$ & Sangat kurang valid & Tidak layak dan perlu revisi besar \\
\hline
\end{tabular}

\section{HASIL DAN PEMBAHASAN}

Materi sistem organ terlalu kompleks dan belum terdapat bahan ajar yang mampu menjabarkan materi tersebut secara ringkas padat dan jelas. Concept mapping book hubungan sistem organ dapat dijadikan bahan ajar tambahan bagi siswa dan mahasiswa untuk lebih memahami tentang hubungan sistem organ. Hal ini akan menunjang pembelajaran yang bermakna.

Concept mapping book hubungan sistem organ dikembangkan dengan menggunakan lima tahapan penting yaitu potensi dan masalah, pengumpulan data, desain produk, validasi desain, revisi desain. Proses pengembangan concept mapping book hubungan sistem organ akan dijelaskan berikut ini.

Potensi dan masalah adalah Langkah awal dalam pengembangan concept mapping book hubungan sistem organ. Pada tahap ini dilakukan analisis kebutuhan concept mapping book hubungan sistem organ dengan melibatkan siswa dan mahasiswa serta pendidik. Kegiatan ini mendapatkan informasi masalah terkait dengan bahan ajar. Bahan ajar yang mampu memberikan informasi terkait sistem organ dalam hal praktis, jelas dan bermakna inilah yang dibutuhkan. Pengumpulan data sebagai rangkaian pengembangan concept mapping book dimulai dengan mengumpulkan literature atau studi Pustaka terkait sistem organ manusia.

Desain produk dilakukan dengan prosedur sebagai berikut: menganalisis kurikulum dan pembelajaran serta silabus perkuliahan. Menentukan indicator dan tujuan pembelajaran yang akan dicapai. Menentukan informasi yang akan disampaikan melalui concept mapping book. Informasi yang disampaikan melalui concept mapping book siswa dapat mendapatkan informasi terkait fungsi organ dan hubungannya dengan sistem organ lain. Desain concept mapping book terdiri dari tampilan dan isinya. Desain tampilan termasuk sampul, warna, font, dan tata letak. Sedangkan isi berupa informasi yang disajikan dalam bentuk concept mapping.

Validasi desain merupakan proses untuk menguji kesesuaian concept 
mapping book dengan kompetensi yang menajdi target belajar. Data mengenai hasil pengembangan bahan ajar berupa Concept Mapping Book diperoleh data bahwa bahan ajar yang dikembangkan layak digunakan. Data hasil validasi dapat dilihat pada Tabel 1.

Tabel 2. Data Hasil Validasi Concept Mapping Book

\begin{tabular}{|c|c|c|c|c|c|c|c|}
\hline \multirow{2}{*}{$\begin{array}{l}\text { Aspek } \\
\text { Penilaian }\end{array}$} & \multirow{2}{*}{$\begin{array}{l}\text { Skor } \\
\text { ideal }\end{array}$} & \multicolumn{3}{|c|}{ Skor yag diperoleh } & \multicolumn{3}{|c|}{ Persentase penilaian } \\
\hline & & $\begin{array}{c}\text { Ahli } \\
\text { bahan } \\
\text { ajar }\end{array}$ & $\begin{array}{c}\text { Ahli } \\
\text { materi }\end{array}$ & Pengguna & $\begin{array}{c}\text { Ahli } \\
\text { bahan } \\
\text { ajar }\end{array}$ & $\begin{array}{c}\text { Ahli } \\
\text { materi }\end{array}$ & Pengguna \\
\hline $\begin{array}{l}\text { Komponen } \\
\text { kelayakan } \\
\text { materi/isi }\end{array}$ & 44 & - & 43 & 44 & - & $97,72 \%$ & $100 \%$ \\
\hline $\begin{array}{l}\text { Komponen } \\
\text { penyajian } \\
\text { materi/isi }\end{array}$ & 48 & 46 & 48 & 32 & $95,83 \%$ & $100 \%$ & $66,66 \%$ \\
\hline $\begin{array}{l}\text { Komponen } \\
\text { bahasa, } \\
\text { gambar, dan } \\
\text { foto }\end{array}$ & 32 & 27 & - & 29 & $84,37 \%$ & - & $90,62 / 5$ \\
\hline $\begin{array}{l}\text { Komponen } \\
\text { grafika }\end{array}$ & 48 & 48 & - & 32 & $100 \%$ & - & $66,66 \%$ \\
\hline \multicolumn{2}{|c|}{ Persentase rata-rata } & & & & $93,4 \%$ & $98,86 \%$ & $80,98 \%$ \\
\hline \multicolumn{2}{|c|}{ Kriteria } & & & & $\begin{array}{l}\text { Sangat } \\
\text { valid }\end{array}$ & $\begin{array}{l}\text { Sangat } \\
\text { valid }\end{array}$ & Valid \\
\hline
\end{tabular}

Setelah tahapan validasi concept mapping book hubungan sistem organ layak dijadikan sebagai bahan ajar tambahan. Namun, sebelum digunakan dalam kegiatan pembelajaran, perlu adanya peningkatan berdasarkan saran dari validator.

Revisi desain dilakukan dengan memperbaiki desain berdasarkan saran dari validator yaitu sampul dan tata letak. Memperbaiki concept mapping book bertujuan untuk mendapatkan concept mapping book hubungan sistem organ yang terbaik dan bermakna.

Dari penelitian dan pengembangan yang dilakukan terhadap pemetaan concept mapping book diperoleh data hasil penelitian berupa model pemetaan concept mapping book hubungan sistem organ manusia dan data pengembangan bahan ajar berupa concept mapping book hubungan sistem organ. Model pemetaan concept mapping book hubungan sistem organ memuat 9 (sembilan) pemetaan hubungan sistem organ. Model pemetaan concept mapping book hubungan sistem organ dapat di lihat pada Gambar 1, Gambar 2, dan Gambar 3. 
HUBUNGAN ANTARA SISTEM PENCERNAAN DAN SISTEM GERAK

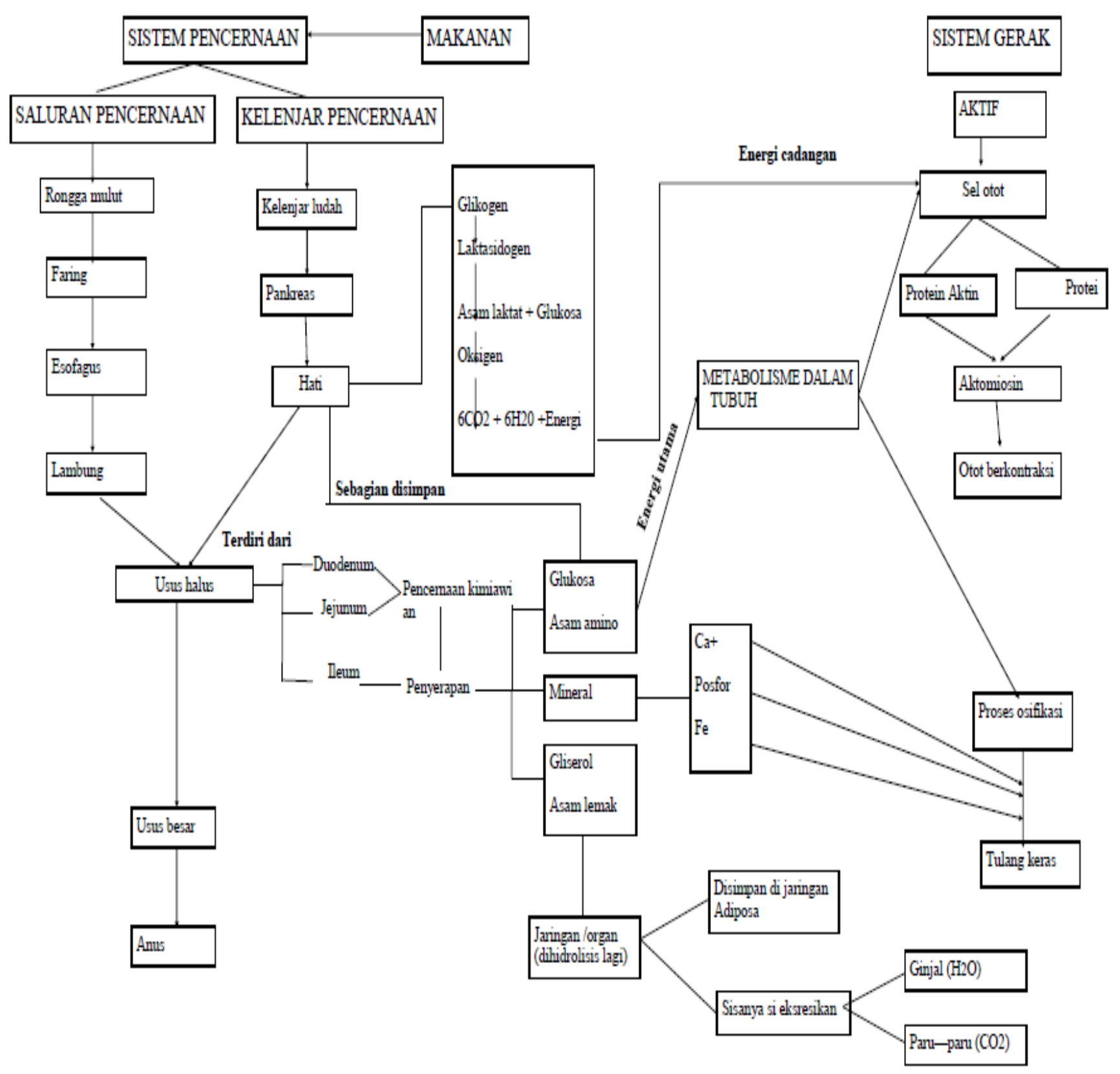

Gambar 1. Pemetaan Concept Mapping Book Hubungan Sistem Pencernaan Dan Sistem Gerak 


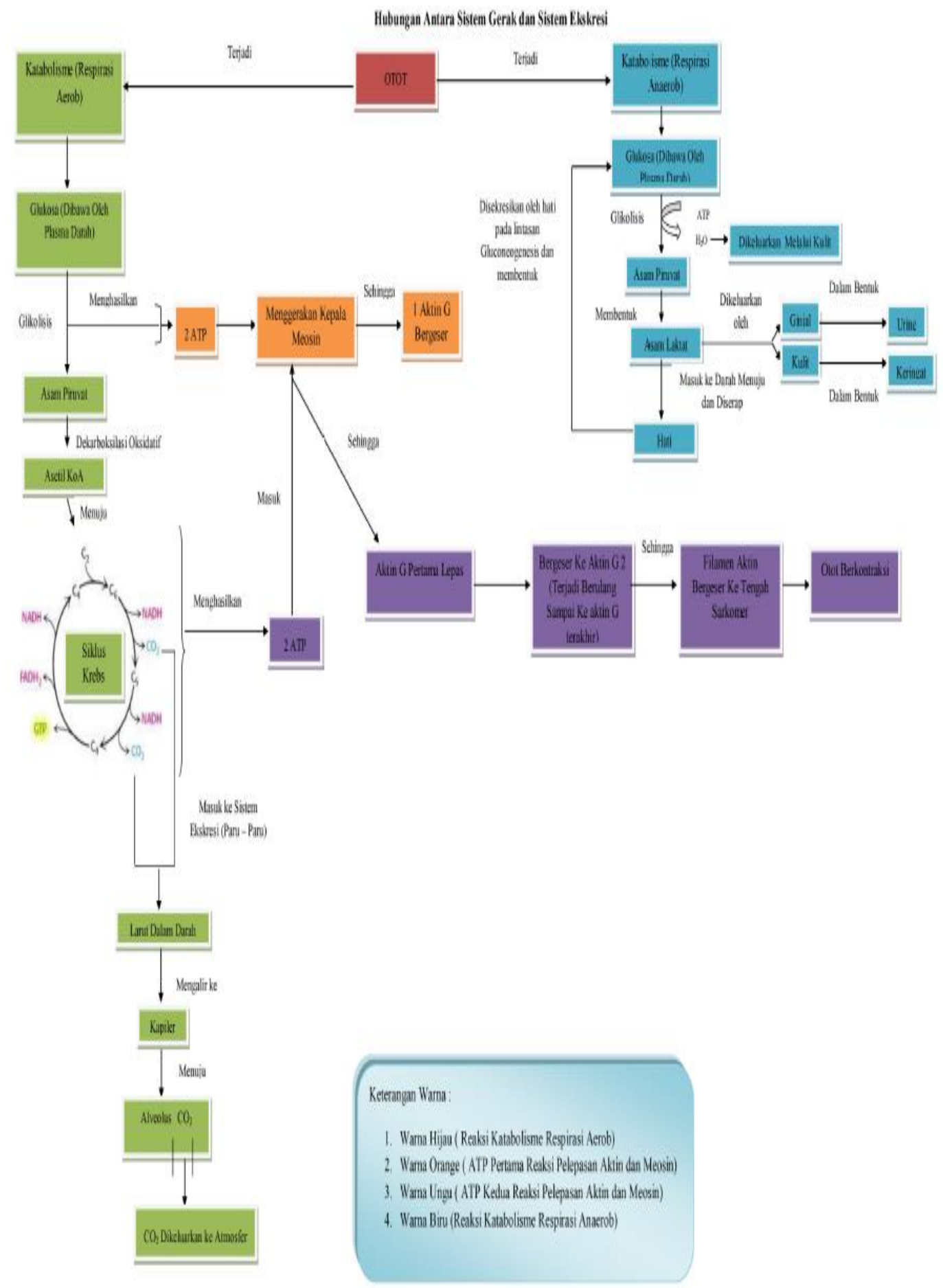

Gambar 2. Pemetaan Concept Mapping Book Hubungan Sistem Gerak dan Sistem Ekskresi 


\section{HUBUNGAN SISTEM PENCERNAAN DENGAN SISTEM EKSKRESI}

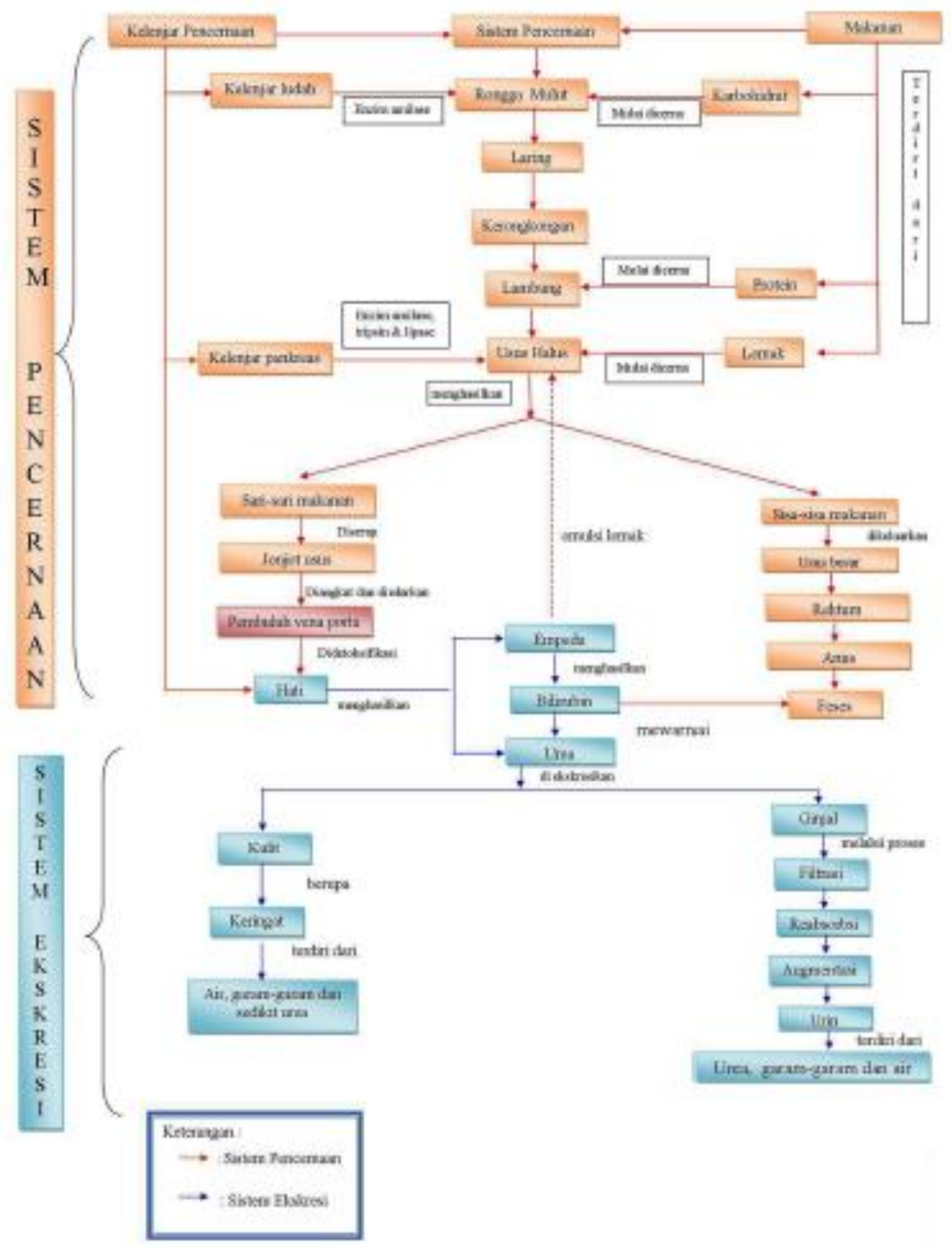

Gambar 3. Pemetaan Concept Mapping Book Hubungan Sistem Pencernaan Dan Sistem Eksresi 


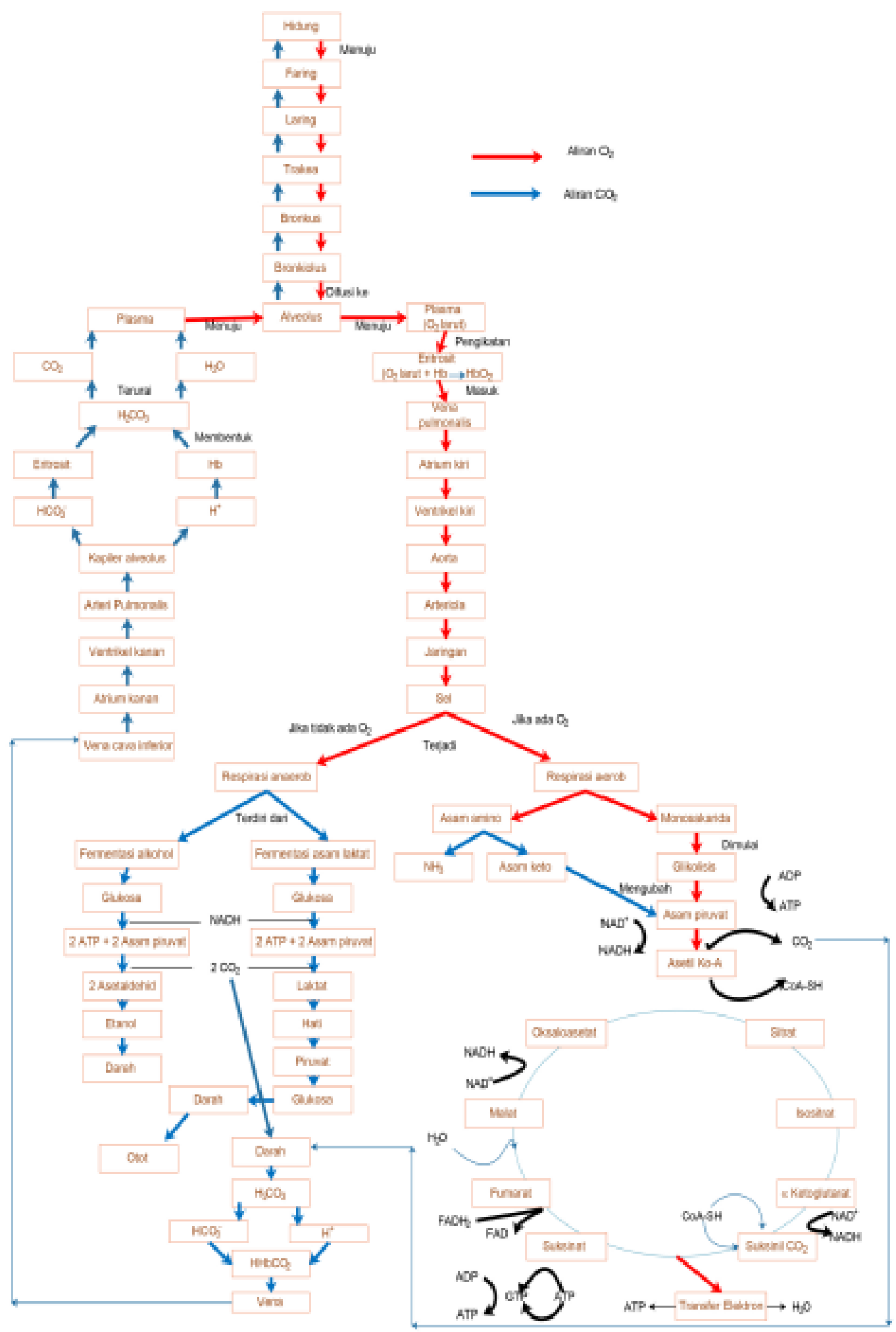

Gambar 4. Pemetaan Concept Mapping Book Hubungan Sistem Sirkulasi Dan Sistem Respirasi 
Hasil penelitian berupa pengembangan Concept Mapping Book hubungan sistem organ diperoleh bahan ajar berupa Concept Mapping Book yang valid dan layak digunakan sebagai bahan ajar. Bahan ajar Concept Mapping Book hubungan sistem organ berasal dari analisis berbagai sumber pustaka yang dirangkum dalam bentuk pemetaan, karena materi yang disajikan di pustaka terlalu luas. Concept mapping adalah sebuah metode yang memungkinkan guru untuk mengajak siswa belajar konsep sains karena concept mapping selalu berhubungan dengan konsep dan mengvisualisasi hubungan tersebut (Akcay , 2010). Concept mapping juga mengfasilitasi validasi berpikir kritis dengan grafis yang mampu menggambarkan kedalaman konsep (Harris \& Shenghua, 2017. Selain itu, concept mapping adalah alat grafis untuk mengorganisir dan menggambarkan pengetahuan (Lunce, 2011). Penelitian pengembangan bahan ajar berupa Concept Mapping Book merupakan salah satu upaya yang dapat dilakukan untuk membantu mahasiswa/siswa memahami materi yang abstrak dan luas. Hal ini sesuai dengan pendapat Concept mapping adalah sarana untuk membangun pengetahuan, memahami apa yang dipikirkan siswanya tentang isi materi, dan memberikan relevansi dan hubungan keterkaitan antar pengetahuan (Campbell L O, 2016).

\section{PENUTUP}

\section{SIMPULAN}

Berdasarkan hasil kesimpulan desain model pemetaan memuat ringkasan materi ajar karena bersumber dari analisis buku yang dirancang secara ringkas dengan tujuan memudahkan mahasiswa belajar secara mandiri dan dapat dijadikan sebagai bahan ajar. Bahan ajar berupa Concept mapping Book yang dikembangkan layak untuk digunakan, hal ini dilihat dari persentase kevalidan yang diperoleh. Untuk persentase kevalidan dari ahli bahan ajar sebesar 93,4\%, ahli materi $98,86 \%$ dan mahasiswa sebagai pengguna $80,98 \%$.

\section{UCAPAN TERIMA KASIH}

Tim peneliti mengucapkan terima kasih kepada Lembaga Penelitian dan Pengabdian (LPPM) Universitas Bengkulu yang telah memberikan dana Hibah Skim Pembinaan Tahun 2018 melalui dana PNBP UNIB 2018 dengan nomor kontrak 1529/UN30.15/LT/2018.

\section{DAFTAR PUSTAKA}

Akcay H. (2010). Constructing Concept Maps to Encourage Meaningful Learning in Science Classroom Education 138 No 1 9-16.

Arikunto S 2012 Dasar-Dasar Evaluasi Pendidikan Edisi 2 Jakarta: Rineka Cipta.

Campbell L O. (2016). Concept Mapping: An " Instagram" of Student' Thinking The Social Studies 107 No 2 74-80.

Ekaputri R Z, Bhakti K, Nike A, Alif Y Z, Aceng R, and Winda Z. (2018). Behavior, Paradigm, Responses and Concern Students' on The Outdoor Learning Paper Seminar Internasional Medan ICST Unpublished.

Fahmy R, Nasri B, Rida R and Melini M (2015). Measuring Student Perceptions to Personal Character Building in Education: An Indonesia Case in Implementing New Curiculum in High School Procedia Sosial and Behaviour Scinces 211 851-858. 
Harris C M, Shenghua Z. (2017). Concept Mapping For Critical Thinking: Efficacy, Timing, \& Type Education 137 277280.

Hay D, Ian K. (2008). Using Concept Mapping to Measure Learning Quality Education Training 50 Issue 2 167-182.

Joshi U, Sheetal V. (2018). Assesment of Perception and Effectiveness of Concept Mapping in Learning Epidemiology 2018 Indian Journal of Community Medicine 43 Issue 1 37-40.

Lampiran Peraturan Menteri Pendidikan dan Kebudayaan Republik Indonesia No 20 Tahun 2016. (2016) Tentang Standar Kompetensi Lulusan Pendidikan Dasar dan Menengah Bab II.

Lunce C. (2011). Concept Mapping in Grades K-12 School Library Monthly XXVII No 8 39-40.

Peraturan Presiden Republik Indonesia No 87 Tahun 2017. (2017). Pasal 7 Tentang Penguatan Pendidikan Karakter.

Shawket I M. (2016). Educational Methods Instruct Outdoor Design Principles: Contributing to a Better Environment. Procedia Environment Scince 34 222232.

Sugiyono. (2008). Metode Penelitian Pendidikan Bandung: Alfabeta. 